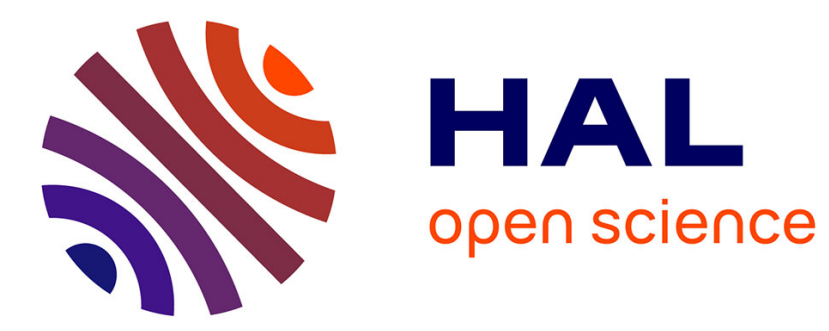

\title{
Changes in the hydrological response of a small Mediterranean basin a year after a wildfire
} Jacques Lavabre, Daniel Sempere Torres, Flavie Cernesson

\section{To cite this version:}

Jacques Lavabre, Daniel Sempere Torres, Flavie Cernesson. Changes in the hydrological response of a small Mediterranean basin a year after a wildfire. Journal of Hydrology, 1992, 142, pp.273-299. 10.1016/0022-1694(93)90014-Z . hal-01575737

\section{HAL Id: hal-01575737 https://hal.science/hal-01575737}

Submitted on 20 Nov 2019

HAL is a multi-disciplinary open access archive for the deposit and dissemination of scientific research documents, whether they are published or not. The documents may come from teaching and research institutions in France or abroad, or from public or private research centers.
L'archive ouverte pluridisciplinaire HAL, est destinée au dépôt et à la diffusion de documents scientifiques de niveau recherche, publiés ou non, émanant des établissements d'enseignement et de recherche français ou étrangers, des laboratoires publics ou privés. 
Changes in the hydrological response of a small Mediterraneān bāsin a year âfter à wildfire

\author{
Jacques Lavabre", Daniel Sempere Torres" and Flavy Cernesson"
}

"CEMAGREF, Le Tholonet B.P., 31 F-13612 Aix-en-Provence, France

"Universiltat Politècnica de Catalunya, Dpi. Euginyeria Hidrùulica $i$ Hidrèdoglca, Gran Capltù̆ s/1H-

MODUL DI, E=08034, Barcelona, Spain 


\section{INTRODUCTION}

It is widely known and accepted that the destruction of the forested ecosystem of a basin has important consequences for its hydrological behaviour. On the one hand, the disappearance of the vegetal caver directly modifies the processes of interception and evapotranspiration, seriously affecting the hydrological cycle. On the other band, forest fires can also affect hydrological processes indirectly, but profoundly, altering the physical and chemical properties of the soil, converting organic ground cover to soluble ash, modifying the microclimate through removal of overhead fol.age, or giving rise to phenomena such as water repellency (Chandler et al., 1983).

However, even if the general consequences of fire have been largely studied, in particular the ecological and biological impact and the associated soil alteration, there are relatively few studies evaluating the effect of these changes on the hydrological response (see reviews by Anderson et al., 1976, and Tiedemann et al., 1979). This relative scarcity of quantitative hydrological studies merely reflects the difficulty of obtaining good quality data to compare hydrological behaviour before and after a fire. Scientific interest in a burnt area generally starts only after the fire, and therefore it is very diflicult to find previous studies and pre-fire data to compare.

A possible solution, often used in fire studies, consists of monitoring two twin basins: the first preserved in its original state, the second artificially burnt. However, even if this strategy may be interestingly used in other fields, the hydrological comparison between twinned basins (supposed hydrologieally equivalent a priori) is very often difficult and the consequences are usually dubious. Of course, a much better strategy is to monitor an experimental basin, collect data over a long period of time (at least ten years), long enough for the characteristics of its hydrological behaviour to become clear, ad then produce an experimental and controlled fire.

In our case a fortuitous wildfire in an area we had been studying for 23 years gave us the chance to study the hydrological effects of tire.

In August 1990 a set of Mediterranean experimental research basins which had been studied since 1966 were partially burnt. The consequences of the wildfire, especially the destruction of the vegetation cover and the alteration of soil, were the only changes produced. Thus the comparison between the pre-fire and the post-fire conditions and between the nested sub-basins can be fairly carried out. The profusion and the quality of the data collected during the pre-fire period and the possibility of comparing the hydrological consequences on similar basins differently affected by the fire, lends this study a special relevance.

In this paper we oresent the first hydrological results and conséquences observed during the first year after the fire. Two aspects, considered the main hydrological changes by other authors (Rowe et al., 1954; Brown, 1972; Campbell et al., 1977; Chandler et al., 1983, Scott and van Wyn, 1990), have 
been especially analysed: (1) the changes in the annual runoff response, and (2) the changes in the flood regime. 
The Réal Collobrier is an experimental research basin that has been observed and gauged continuously since 1966 by the CEMAGREF group from Aix-en-Provence, France. This basin $\left(43^{\circ} 14^{\prime} \mathrm{N}, 6^{\circ} 13^{\prime} \mathrm{E}\right)$, located in the Maures massif (Var Department, France, see Fig. 1) near the Mediterranean sea (about $15 \mathrm{~km}$ away), is in fact a set of nested -sub-basins with marginal human influence. The measurement network consists of 17 pluviographs, spread over an area of $100 \mathrm{~km}^{2}$, a meteorological station and 11 flow recorder

stations (with basin areas between 70 ha and $70 \mathrm{~km}$ "), some of which are equipped with a water temperature sensor, conductivity sensor and sampler (Lavabre, 1990; Sempere Torres, 1990).

In August 1990 a severe fire partially affected this area (more than 8000 ha destroyed in 3 days). Depending on the sub-basin, the portion ofburnt surface varies from 0 to $85 \%$ (Lavabre et al., 1991). The present study concerns the Rimbaud basin, a 146ha nested sub-basin with elevations ranging from 470 to $622 \mathrm{~m}$ (see Fig. 1), in which the fire destroyed $85 \%$ of the vegetation,

This basin can be considered as geologically homogenous, underlain by slightly altered gneiss. Its thin, sandy soils are of the Rankcr type. Shrubby maquis and degraded forest of cork trees, chestnuts and maritime pines had occupied the basin totally before the fire. Table 1 summarises the main characteristics of the basin.

The uirn of this paper is to analyse and compare the hydrological response of the Rimbaud basin before and after the fire (see Fig. 2). To this end, we considered the 23 year pre-fire period as the reference period defining the normal behaviour for the basin. Sorne linear regressions and a lumped conceptual model have been caiibrated, and used to simulate what the response would have been if the fire had not occurred. Differences between these simulations and the response observed are analysed herein. A complementary comparison with the response of the Vaubarnier, a nearby subbasin of 148 ha which was not affected by the tire (see Fig. 1), is also provided. A complementary analysis of chemical and mechanical erosion has been carried out by Martin and Chevalier(1991).

\section{CHANGES IN THE ANNUAL RUNOFF RESPONSE}

First let us consider the hydrological year $N$ as the 12 mon th period starting on I August of the year $N$. Thus in our study the reference period before the fire eomprises the hydrological years 1967-1989 (from August 1967 until July. 1990). The study period was the hydrological year 1990 (from August 1990 to July 1991). Note that the tire took place between 22 and 24 August 1990. Nevertheless, no rainfall had been recorded since June and no flow was 


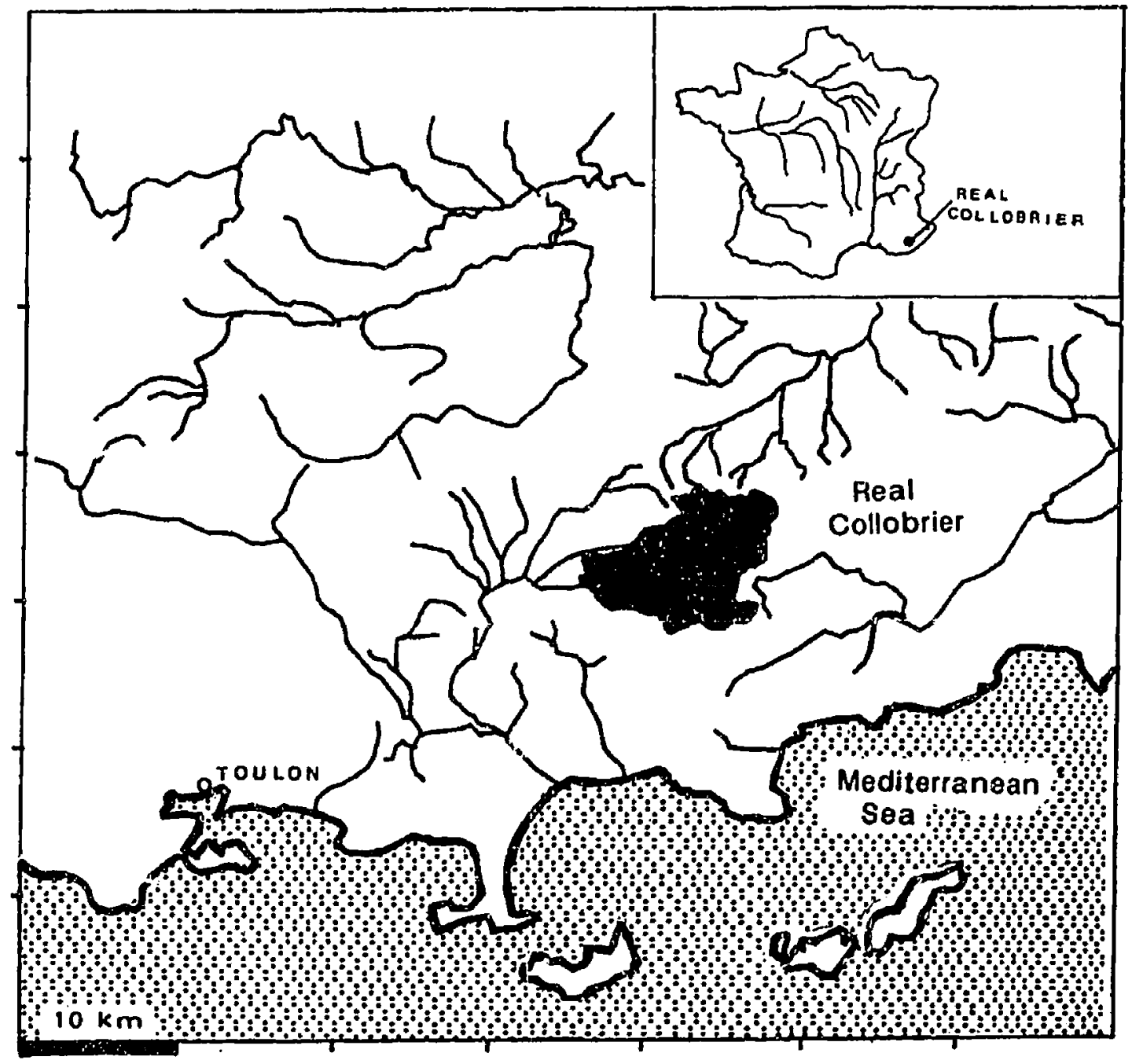

Fig. 1. Location of the Réal Collobrier expérimental rescarch basin and of the Rimbaud and Vaubarnier sub-basins.

recorded during August. Thus the 1990 hydrological year can be considered to be totally post-fire.

The data were continuously recorded during this period and only the flows from 5 to 25 October were missed. In the study, the monthly total flow of October was reconstituted using the next flow recorder station located in the Rimbaud stream. For the precipitation data we used the values measured by the pluviograph located inside the basin. Complementary data from the Réal Collobrier meterological station nearby were also used. 


\section{0}

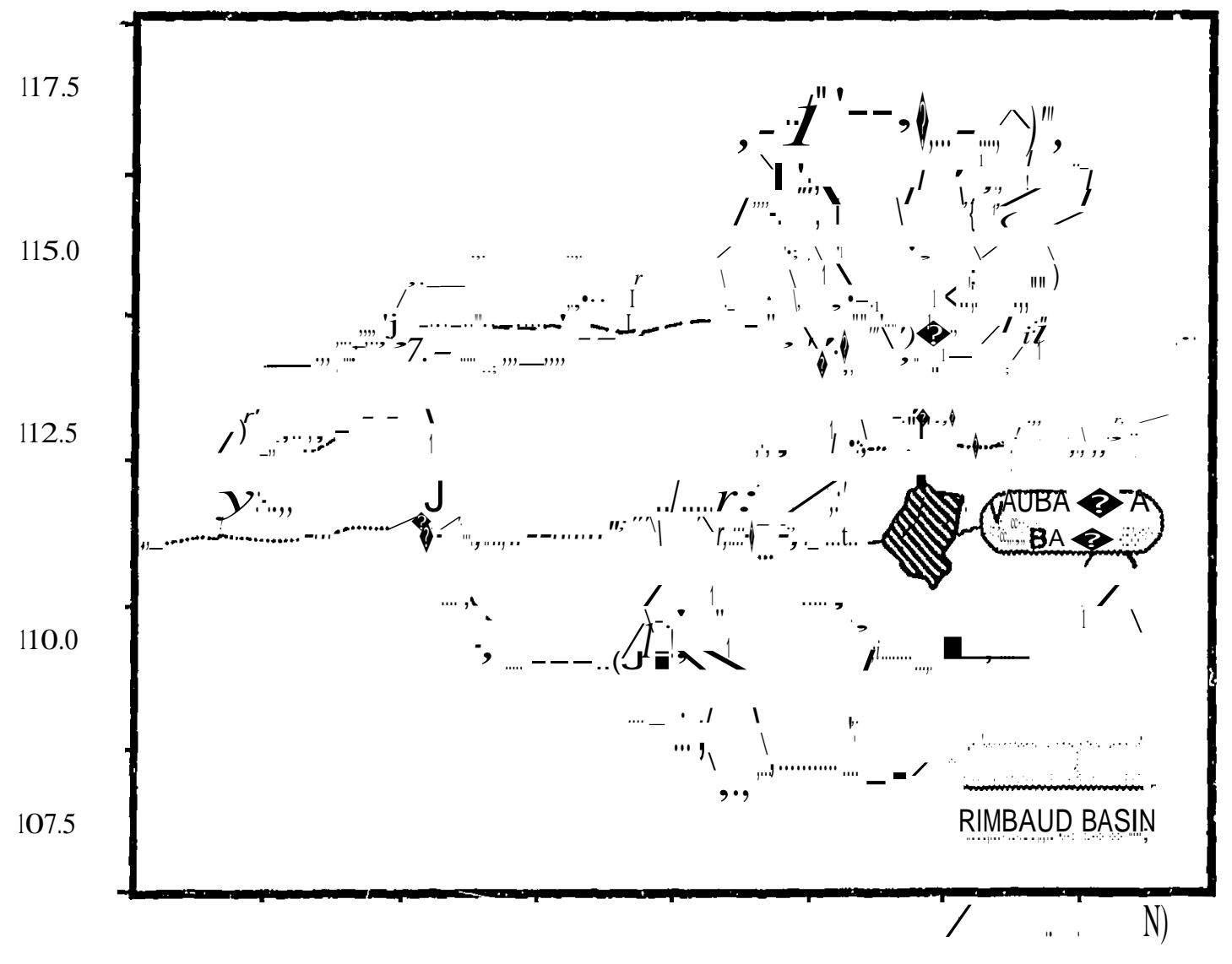

105.0

$\begin{array}{lllllllll}910.0 & 912.5 & 915.0 & 917.5 & 920.0 & 922.5 & 925.0 & 927.0 & 930.0\end{array}$

Fig. 1 (continued),

Km (Lambert 111)

\section{TABLE 1}

Summary of the main characteristics of the Rimbaud basin before the fire (1967-1989)

surface area

Distance to the sea

Elevation range

Vegetation

Gcology

Annual mean precipitation

Mean discharge

Maximal discharge

\section{Wyear returm period flow}

Human influence 
140ha

$15 \mathrm{~km}$

470-670m

Totally forested by

maquis and degraded forest of cork trees and chestnuts

Slightly altered gneiss

$1164 \mathrm{~mm}$

$201 \mathrm{~s}-{ }^{1}$

$13.7 \mathrm{~m}^{3} \boldsymbol{\mathcal { G }}^{1}$

$6 \mathrm{~m}^{3} \mathrm{~s}-{ }^{1}$

Marginal 

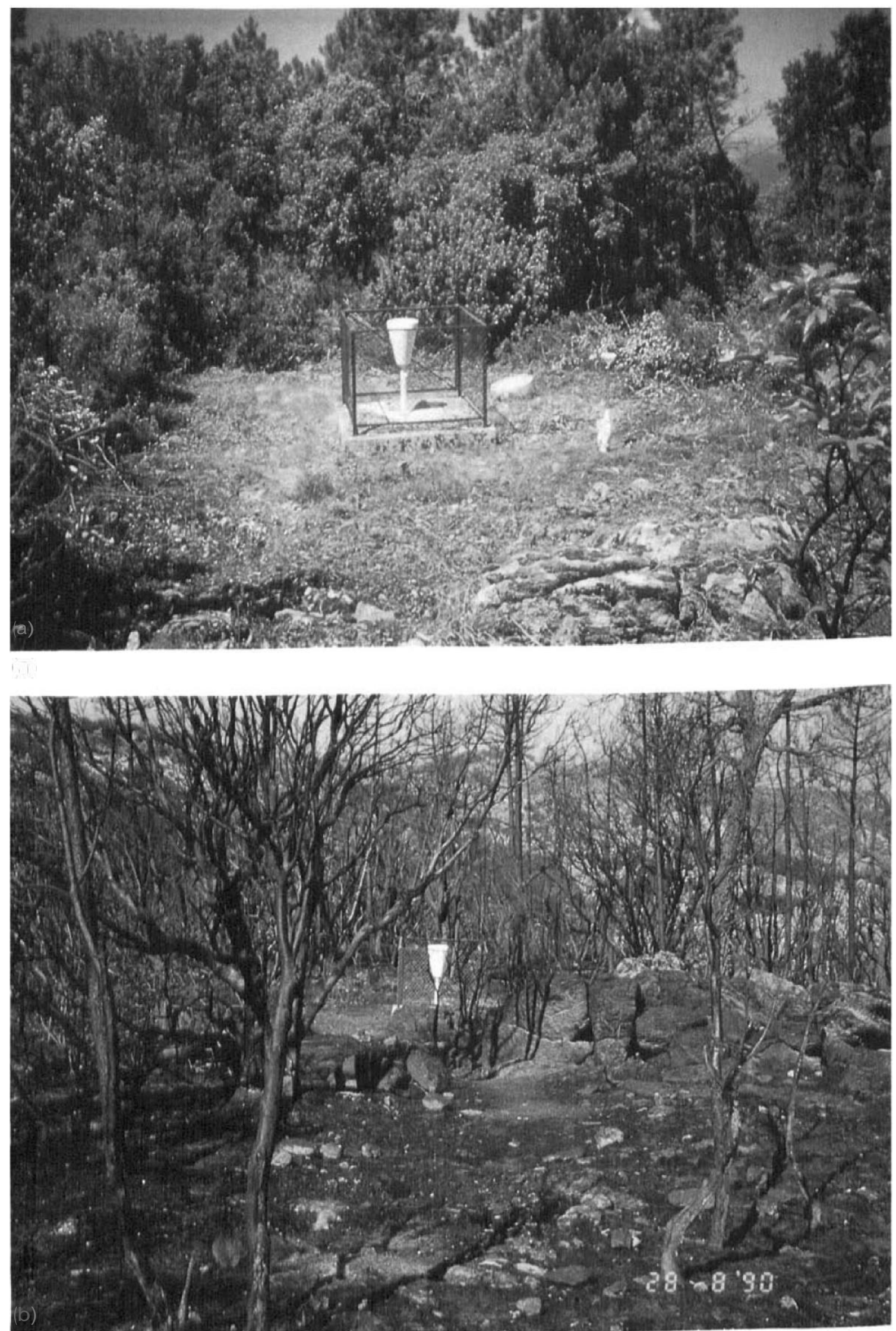

Fig. 2. The Rimbaud pluviograph area (a) bcforc and(b) after the firc. 
Main statistical characteristics of the 23 year reference period (1967-1989)

\begin{tabular}{lccc}
\hline & Annual & Annual & Annual \\
& & & 538 \\
Mean $(\mathrm{mm})$ & 1164 & 626 & 67 \\
Standard deviation $(\mathrm{mm})$ & 366 & 325 & 12 \\
Variation coefficient $(\%)$ & 31 & 52 & 105 - \\
\hline
\end{tabular}

Annual analysis

A hydrological year can be simply described by the annual precipitation $(A P)$ and by the annual runoff $(A R)$. We can define the annual losses $(A L)$ as $A L=A P-A R$

Now, our purpose is to set a prediction of the $A R$ for 1990 based on the reference period and compare it with the observed $A R$. Table 2 shows the main statistical characteristics for the 23 year reference period, i967-1989.

The relatively high rainfall is a consequence of the proximity to the sea and the orographie role of the massif in the genesis of precipitation. The small variation coefficient of the $A L$ shows that they are relatively stable around the mean value. This suggests that the annual variability of the $A P$ is practically absorbed by the $A R$, and that the $A L$ are little influenced by the pluviometry.

So, given that the geological structure of the basin allows us to ignore the existence of deep tosses, the $A L$ may be considered as an estimate of the real evapotranspiration. (Note that the annual potential evapotranspiration measured by Colorado bac is $1155 \mathrm{~mm}$, see Table 5.) On the other hand, on the basis of the $A L$ stability, we can propose that a linear regression could be a good tool to relate the variability of $A R$ to that of $A P$. Thus the established eqn. (2) will be used to predict the $A R$ for 1990.

$$
A R(\mathrm{~mm})=0.88 A P(\mathrm{~mm})-396 \quad \mathrm{R}^{2}=0.98 ; \quad \text { ares }=51 \mathrm{~mm}(2)
$$

The high correlation coefficient between $A R$ and $A P(R=0.988)$ confirms the good quality of the equation, which accounts for $98 \%$ of the initial $A R$ variance and that has a residual standard deviation (ures) of $51 \mathrm{~mm}$. It is worth noting that the reference period covers a wide range of situations, thus increasing the robustness of the relation. Table 3 shows the extreme values of $A P$ recorded during this period, illustrating this statement and, at the same time, the well known high variability of the precipitations characterising the Mediterranean climate.

As a consequence, we will expect that this equation will be valid in the case 


\section{TABLE 3}

Extreme values of $A P$ and $A R$ during the reference period (1967-1989)

\begin{tabular}{llc}
$\begin{array}{l}\text { Hydrological year } \\
(\mathrm{mm})\end{array}$ & $\begin{array}{l}\text { Annual precipitation } \\
(\mathrm{mm})\end{array}$ \\
\hline 1973 & & 1219 \\
1976 & 1776 & $\mathrm{~J} 186$ \\
1988 & 1880 & 111 \\
1989 & 545 & 85
\end{tabular}

of the 1990 hydrological year: the $A P$ observed, $977 \mathrm{~mm}$, is inside the range of usefulness of the equation. It is slightly lower than the mean, but higher than the two last years which do not exceed $600 \mathrm{~mm}$.

However, the estimate of the annual runoff provided by the regression eqn. (2) is $464 \mathrm{~mm}$ whereas the observed annual runoff was $576 \mathrm{~mm}$, a difference of $112 \mathrm{~mm}$ (greater than 2.2 times ares). Note that accepting a normal distribution of the residual, the probability that this difference might be due to a hazard fluctuation is less than $1 \%$. Therefore we can conclude that the $A R$ observed in 1990 cannot be explained correctly by the relation obtained during the reference period. This conclusion in fact recognises that the fire has led to significant changes in the hydrological behaviour of the basin. So, we can estimate that the increment of annual runoff due to the change of basin chracteristics, or alternatively the reduction of retention and loss ability of the basin, is about $112 \mathrm{~mm}$ (24\% of supplementary runoff),

It could be objected that this year may have been climatically different to the previous years, and that this may have been the main cause of the non-adequacy of the equation. However, when the annual losses $(A P-A R)$ observed in the Rimbaud basin are compared : with those observed in the Vaubarnier basin (not affected by the tire), it is clear that the observation for 1990 represents an anomaly in the usual relation between the two basins (see Fig. 3).

The 1990 point lies outside the envelopc of the pre-fire period $A L$ values. The 1990 Rimbaud $A L$ are extremely low in comparison to the $A L$ recorded in the Vaubarnier, and this difference contrasts ;sharply with the relatively good concordance between the $A L$ of the two basins during the reference period. In this case the Rimbaud shows the lowest value ever observed whereas the Vaubarnier shows the highest.

Again we can conclude that there is a significant reduction of the $A L$ (equivalent to an increase of $A R$ ) in the Rimbaud basin due to the destruction of the vegetation cover. As we said before, we can assimilate this loss 


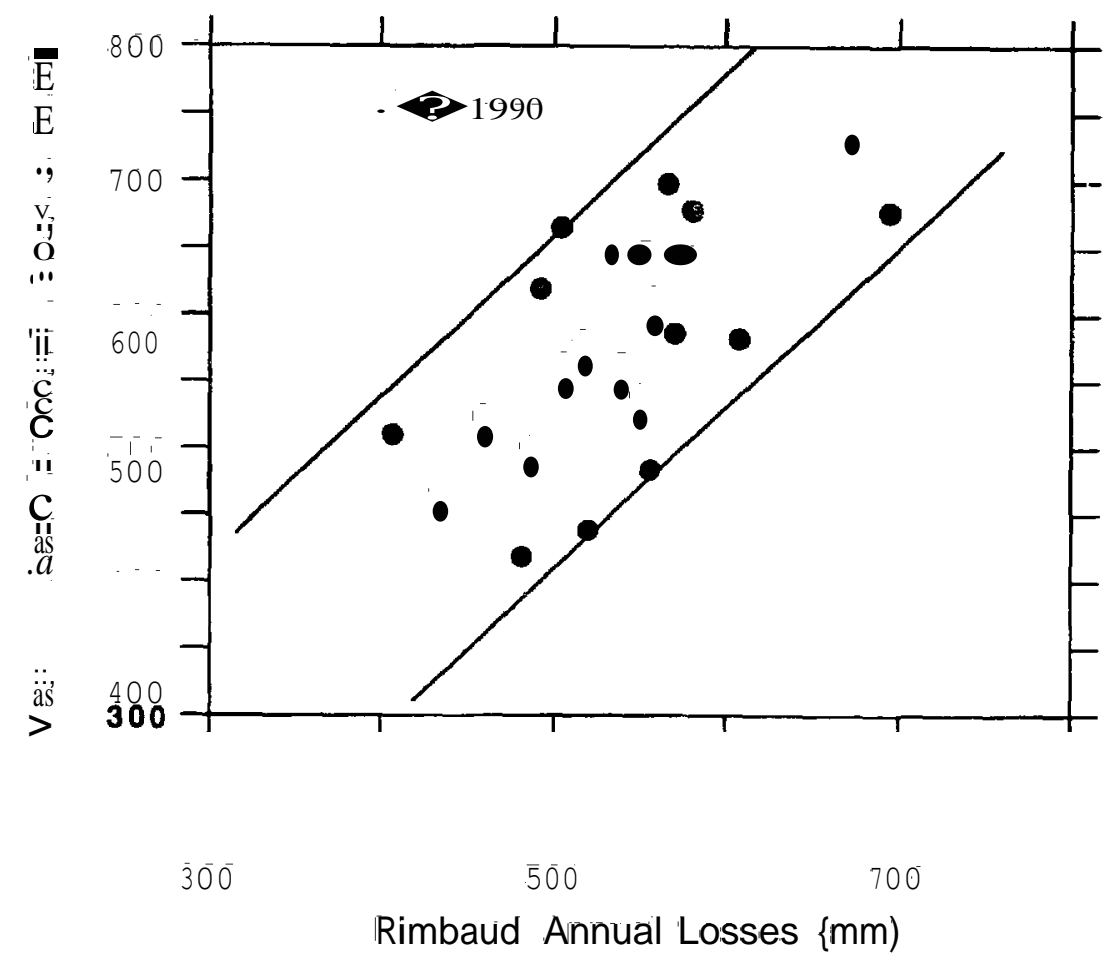

Fig. 3. Comparison of the annual tosses (AL) between the Rimbaud (85\% destroyed by fire) and the Vaubarmier (not affected by lire) basins for the period 1967-1990.

reduiction to the reduction of the real evapotranspiration. Note, however, that using the envelope of Fig. 3, the estimate of the anomaly is much higher than the value estimated by the regression equation (2): about $225 \mathrm{~mm}$, instead of the previous $112 \mathrm{~mm}$. It is "worth nothing that in 1990 the Vaubarnier basin showed especially high tôsses due tó the effect of tne two previous very dry years (even in the case of these small basins, water resources have an interannual regulation). Thus we admit that the difference reported in the losses may be overestimated in this case by the special characteristics of the hydrological year and by the fact that the value of $225 \mathrm{~mm}$ is an upper limit for the estimate of the increment of the $A R(64 \%$ of increment).

Finally it may be interesting to analyse whether the increase of the $A R$ produced by the fire affects the base ftow and the quick flow in similar way. Of course this analysis depends on the method used to separate the two generally accepted components of the flow. Nevertheless, we consider this analysis necessary.

We used the L'vovich algorithm (L'vovich, 1972), which is the reference separation algorithm proposed by the FRIEND European programme and has been applied in the experimental networks of western Europe (Gustard et al., 1989). It provides a base flow separation using daily flowws. We cân thus compare the base flow to the total flow.

In the 1990 hydrological year, the ratio between base flow and total flow 


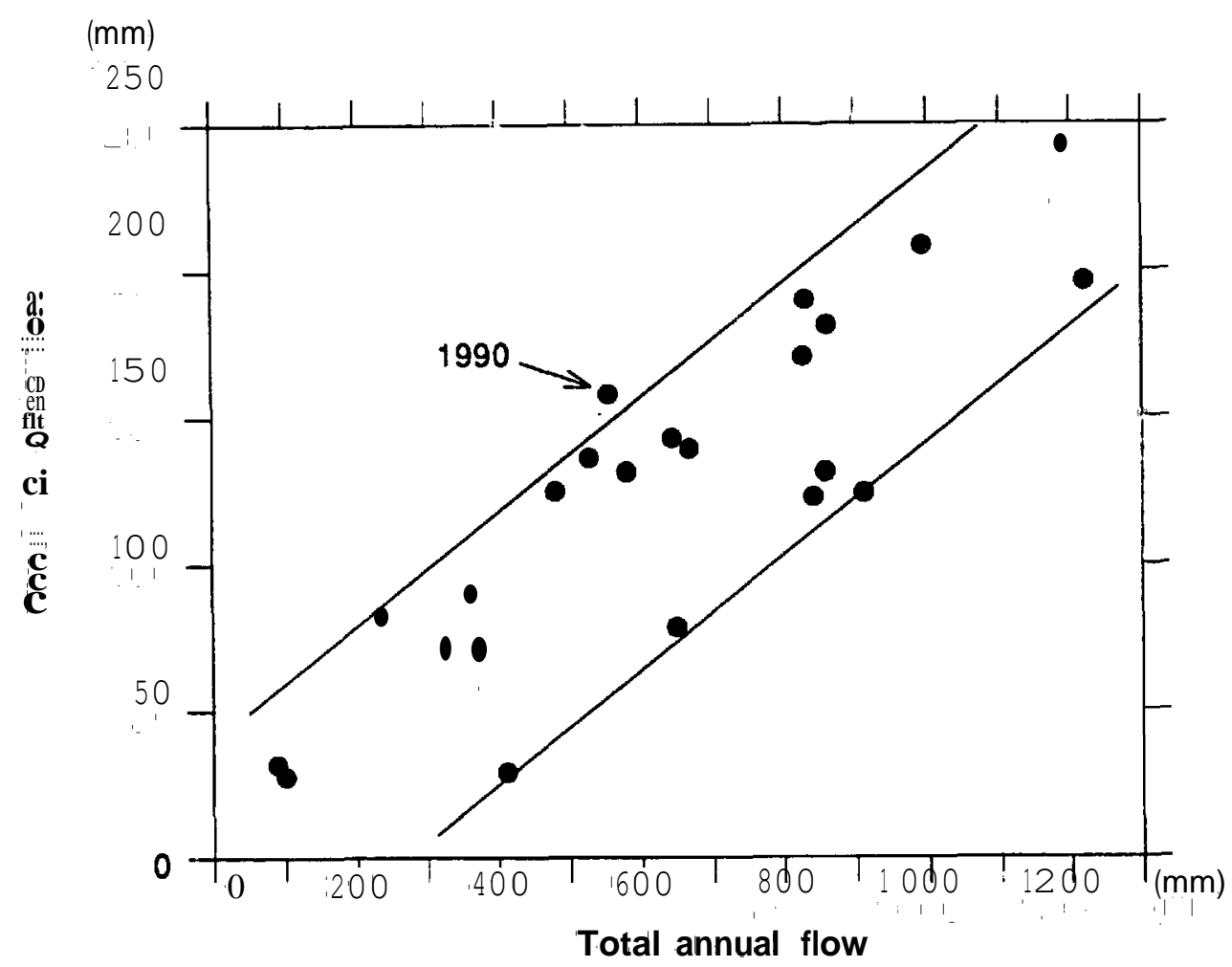

Fig. 4. Relation between annual base flow and total flow for the Rimbaud basin (1967-1990).

is $28.4 \%$. This value is inside the range of ratios observed during the reference period (between $7 \%$ in 1969 and $36 \%$ in 1989). When we compare total annual base flow to total runoff (see Fig. 4) we should point out that the 1990 value is slightly higher than the upper envelope of the reference period values.

Therefore, we cannot make conclusions about an anomaly and we will suppose that the increase in $A R$ is produced on both components.

\section{Monthly analysis}

The median values of monthly precipitation and runoff for the reference period are shown in Fig. 5 (median values are usually used owing to the asymmetry of the runoff). The precipitation distribution shows the classical representation of the Mediterranean climate: a dry period during the summer months but a rainy winter and spring. As for the runoff, it should be noted that:

(1) The precipitation distribution shows good accordance with the pluviometry from January until the summer;

(2) the flow is not permanent and disappears during the dry period;

(3) at the start of the hydrological year, the basin needs high rainfall 


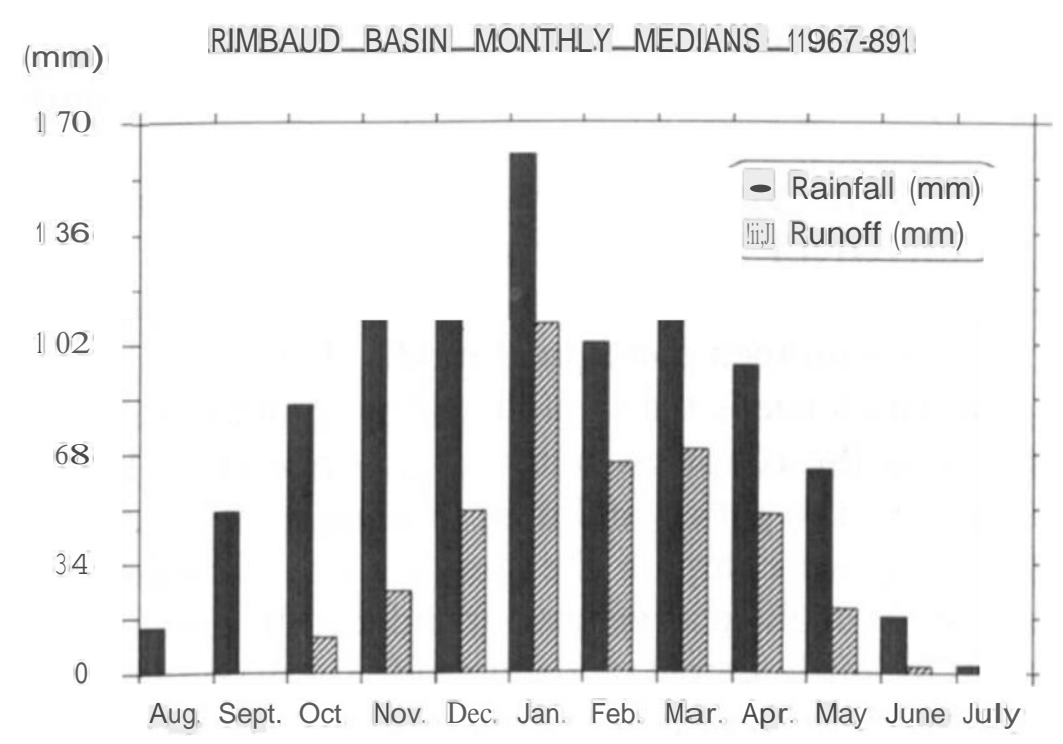

Fig. 5. Median monthly precipitation and runoffduring the reference pcriod (1967-1989).

contributions to reinitiate the permanent flow regime (to refill the initial hydrological deficit (DE)).

The initial deficit, which is related to the necessary soil recharge, has been studied during the reference period and linked to the duration of the nonpermanent flow period (DUR is the number of days without permanent flow from the start of the hydrological year).

The regression equation

$D E(\mathrm{~mm})=1.07$ DUR (number of days) +166

has been established.

This equation provides a good estimate of $D E(R=0.915$; arcs $=19 \mathrm{~mm})$. The fixed term $(166 \mathrm{~mm})$ is related to the storage capacity and the variable term represents the influence of the delay in reaching the permanent flow regime; the later the permanent flow is attained, the higher the deficit to be refilled is, since it implies- that the intermediate precipitations are in fact lost by evapotranspiration (very high during this period, see Table 5).

For this year, despite some floods at the start of October, the flow was not permanent until 12 October. Thus eqn. (3) predicts an initial deficit of $242 \mathrm{~mm}$ instead of the $165 \mathrm{~mm}$ of accumulated rainfall recorded until this date.

Again, a complementary estimate leads us to conclude that there was a reduction of the losses in 1990. In this case the difference between predicted and observed deficit is about $77 \mathrm{~mm}$ (32\% of reduction), and again this difference cannot be explained by the normal hazard fluctuations (it is more than three times greater than the ares of the equation). Note, however, that this deficit is only related to the initial losses, and that this figure of $77 \mathrm{~mm}$ is only 
a part of the annual reduction of the losses previously estimated. Therefore only the relative evaluation (32\%) can be compared with the previous estimates.

A second monthly analysis was also carried out. A hydrological model, GR3, proposed by the CEMAGREF group (Michel, 1983) and usually used as a reference model in France, was used to reproduce the monthly chronology of the runoff. It is a lumped conceptual model that has only two calibrating parameters and which needs the rainfall and the potential evapotranspiration as inputs, giving the runoff as output (see Appendix). It was calibrated over the 23 year reference period and used to simulate the monthly runoff of 1990. Therefore, we can compare the simulated to the observed runoff to state the change of hydrological behaviour induced by the tire.

In the calibration period this quite simple model provided very good results (see Table 4a). The mean monthly residuals are relatively small, the Nash efficiency is $E=0.74$ (Nash and Sutcliffe, 1970), showing that the runoff is estimated fairly and leading to a global difference over the total balance of the 23 year period of less than $1 \%$.

As for the post-fire year (see Table 4b), the comparison between observed and simulated runoff shows that the values simulated by GR3 are systematically underestimated, excepting the summer months, where the model cannot reproduce the very little flow observed, (see Fig. 6). Therefore, assuming that the model simulation is a good representation of what would have been the behaviour of the basin if the fire had not existed, we can state again an increase of the annual runoff of about $148 \mathrm{~mm}(35 \%$ of $A R$ increase) in the new circumstances. Again, this difference cannot only be due to the hazard fluctuations (less than 3\% probability): the residual standard deviation of the regression between the observed annual runoff and the simulated annual runoff in the reference period is <ires $=73 \mathrm{~mm}(R=0.97)$. This difference is once again the hydrological consequence of the tire. We can try to carry this conclusion further.

It was suggested before that the stated increase of the annual runoff must be mainly the consequence of the reduction of evapotranspiration due to the destruction of the vegetation cover (the soil retention power is also affected, but dealing with annual or monthly amounts the most important consequence is the reduction of interception and evapotranspiration). More precisely we should speak about the reduction of interception and transpiration power related to the vegetation destruction since the effects of the canopy removal are thought io increase evaporation because of the insolation and wind increases due to the opening up of the forest floor (Chandler et al., 1983. pp. 185-189). However, in our case, we are not strictly able to separate evaporation from transpiration losses. 


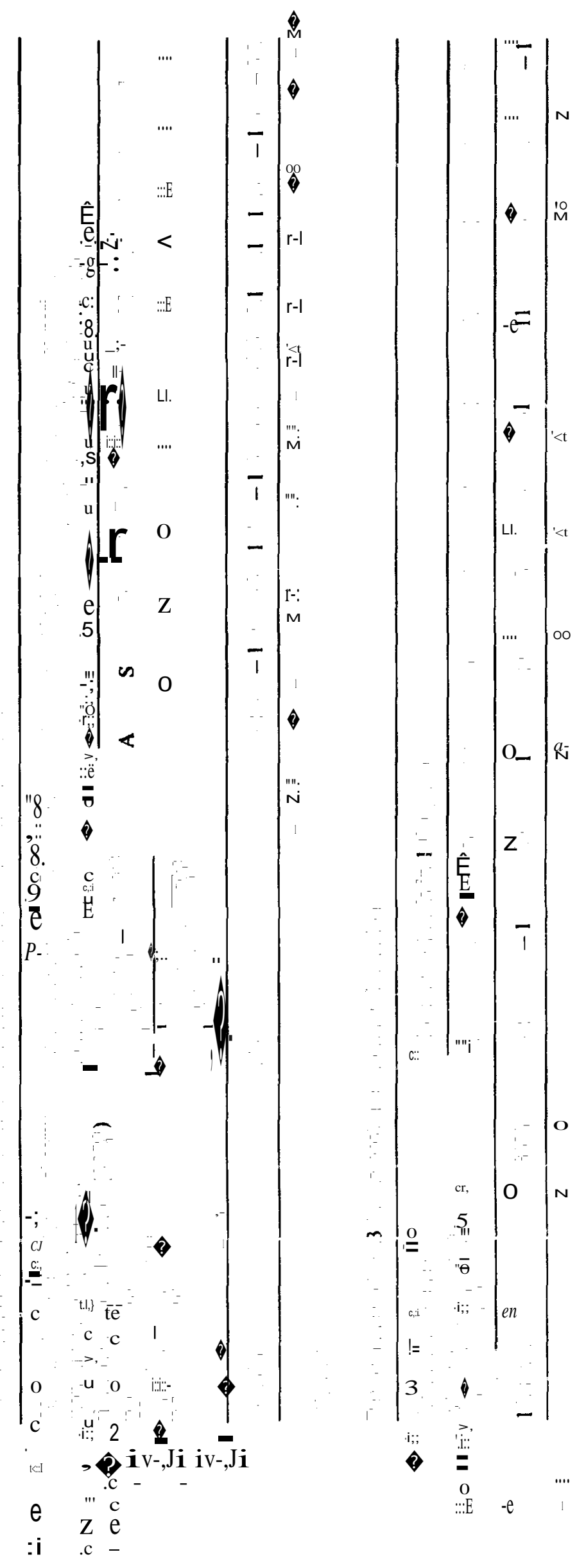


(...'.

c

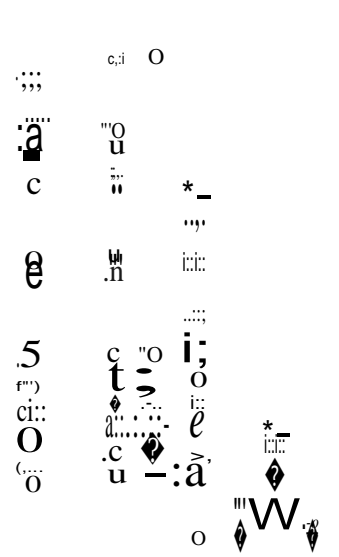

c:, $\quad$ te $i$ :

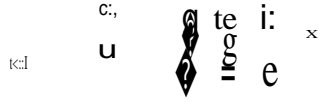

11

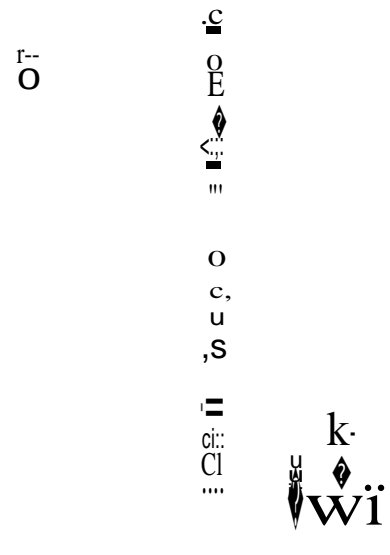

o

.c

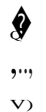

11

$$
\because-\quad \text { is } \quad \text { "'O }
$$

$\mathrm{Tt} "$
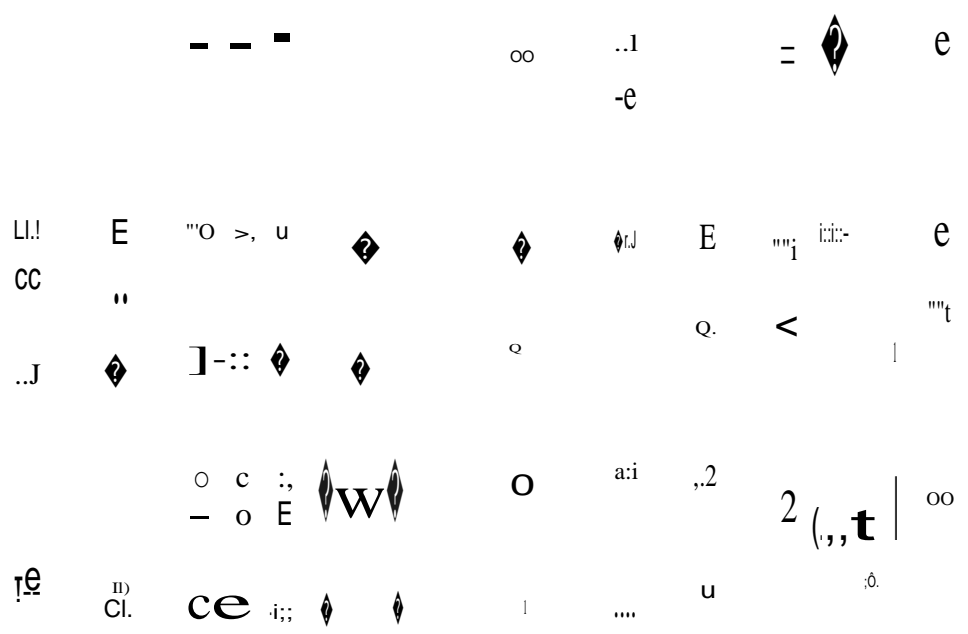

$\underline{T} \underline{\underline{e}}$

cl. ce i; 

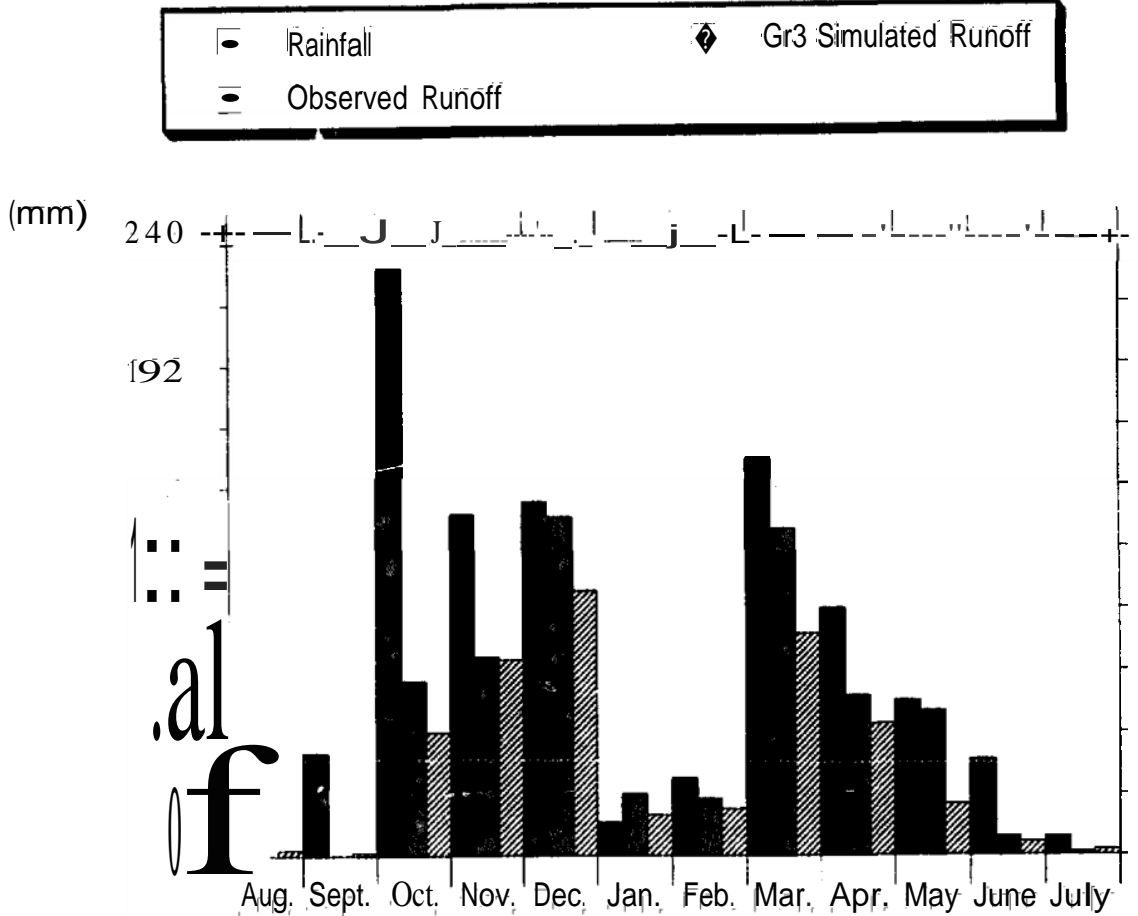

Fig. 6. Comparison between the monthly runoff observed and simülated by $\overline{\mathrm{G}} \overline{\mathrm{R}} \mathrm{3}$ in 1990 .

To corroborate this hypothesis, we repeated the simulation but took into account this reduction and tested whether a reduction of the evapotranspiration values used by the model can produce better rēsultšs. It shoüld be remembered that GR3 only utilises the potentiāl evapotranspiration. Therefore, instead of using the interannual mean of the potential evapotranspiration of the Réal Collobrier as previously (Lavabre, 1989; Lavabre, 1990, see Table 5), we have used different réductions of these initial evapotranspirations.

Finally a 50\% reduction was used to obtain a new simulation which provides better monthly estimates (compare its performance- shown in Table 6 with those of Table 4). Moreover the annual estimate is improved: it is this time slightly overestimated, $19 \mathrm{~mm}$ instead of $148 \mathrm{~mm}$. This confirms that a

\section{TABLE $\overline{5}$}

Monthly pntt>nti I evapotranspiration used for the Rimbaud hw,in (frnltt data at the Réal Cōllobriēer meteoorological station)

\begin{tabular}{|c|c|c|c|c|c|c|c|c|c|c|c|}
\hline Month & $\mathrm{J}$ & $\mathrm{F}$ & $M$ & A & $\mathrm{M}$ & J & J & A & $S$ & $\theta$ & $\mathrm{N}$ \\
\hline $\begin{array}{l}\text { Monthly potential } \\
\text { éváportranspiration } \\
\text { (mm) }\end{array}$ & 180 & 110 & 75 & 40 & 25 & 35 & 30 & 60 & 90 & 140 & 160 \\
\hline
\end{tabular}




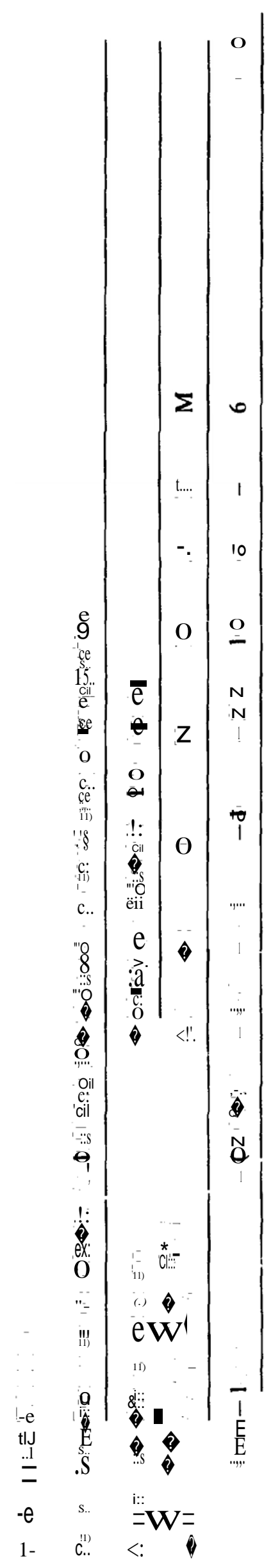


Performances of GR3 in the daily simulation

\begin{tabular}{|c|c|c|}
\hline Nash Efficiency $E$ & $\begin{array}{l}\text { Calibration } \\
\text { period (1984-1989) }\end{array}$ & 1990-1991 \\
\hline Annual ratio between observed and & 0.83 & 0.70 \\
\hline simulated volume of ftoods (\%) & 115 & 162 \\
\hline $\begin{array}{l}\text { Days with ftow greater than four times the } \\
\text { mean daily runoff }\left(>4 \times 201 \mathrm{~s}^{-}\right) \\
\text {Number of observed days }\end{array}$ & & \\
\hline Number of simulated days & 105 & 29 \\
\hline $\begin{array}{l}\text { Difference between observed and simulated } \\
\left.\text { runoff on these days (mm year- }{ }^{1}\right)\end{array}$ & $\begin{array}{r}12 \\
43\end{array}$ & $\begin{array}{r}18 \\
121\end{array}$ \\
\hline $\begin{array}{l}\text { Days with ftow less than one fourth of the } \\
\text { mean daily runoff }\left(<20 / 41 \mathrm{~s}^{\prime}\right) \\
\text { Number of observed days } \\
\text { Number of simulated days } \\
\text { Difference between observed and simulated } \\
\left.\text { runoff on these days (mm year- }{ }^{1}\right)\end{array}$ & $\begin{array}{l}780 \\
514 \\
-9.6\end{array}$ & $\begin{array}{l}113 \\
104 \\
-8.9\end{array}$ \\
\hline
\end{tabular}

$50 \%$ reduction in evapotranspiration leads to similar results to those observed as a consequence of the fire.

We should note that in fact we changed only the potential evapotranspiration (instead of the real evapotranspiration). However, it was the only variable that could be changed in the simple model used. Thus the conclusion should be more precisely stated: that destruction of the vegetation cover induces a change in the loss power that in our case is hydrologically equivalent to a $50 \%$ reduction of the potential evapotranspiration.

\section{Dai/y analysis}

We carried out a similar analysis but using a daily time step. First the model was calibrated on the pre-fire years, and then the model simulation and the daily runoff observed for 1990 were compared. This time the model was calibrated using only a 5 year period which is considered sufficient by the model (1984-1989). Table 7 summarises the performance of the daily simulation.

The results of the post-fire year show again that the mode\} systematically underestimates daily runoff, whereas for the reference period the model tends 
slightly to overestimate it. This bias, reflected in the $E$ reduction, is evidenced both on the total annual runoff and in the daily runoff peaks.

As for the $A R$, observed daily runoff exceeds the daily simulated annual water yield by $100 \mathrm{~mm}$, which is a 22o/0 increase over the estimated "normal' response ( $452 \mathrm{~mm}$ simulated instead of $552 \mathrm{~mm}$ observed). We should note that this estimate does not include the missed period (21 days including relevant storms), and should be taken as a lower limit for the estimate of the increment of the $A R$. This increase does not affect the peak flow in the same way as the recession flow. Table 7 shows different variables regarding the days where daily runoff is more than four times $<S$ great as the mean daily runoff (201 s" $)$, the high water days, and those where the daily runoff is less than one-fourth of the mean daily runoff, the low water days. These results point out that the increase of the runoff volume is practically concentrated on the high water days (a difference between the simulated runoff and the observed of about $120 \mathrm{~mm}$ during these days). The low water days do not show any significant change after the fire (the model bas fewer problems to reproduce correctly the number of these days, which is now reduced). The other index, particularly the ratios of the volume of floods and the number of high water days, confirms the relation between the increase of runoff production and the high water.

On the other band, ifwe compare the peak flow (see Fig. 7), it is confirmed that the new response of the basin can be characterised by sharper and increased peak ftow (similar to that reported by Brown, 1972, and by Burch et al., 1987). The zoom on the two most important daily peaks recorded shows this trend more clearly, which in the case of the higher peak leads the model to predict a peak flow of $4081 \mathrm{~s}^{-1}$ instead of the $6631 \mathrm{~s}^{-1}$ observed $\left(62^{\circ} \%\right.$ of incrcase).

Again, these results are in accordance with the previous estimates. They suggest that the consequences of the fire affect the hydrological response at ail time steps, and lead to a $30 \%$ increase in runoff mainly concentrated in the high water days. (Note that this conclusion is not in contradiction with the conclusions reached concerning Fig. 4.)

\section{CHANGES IN THE FLOOD REGIME}

After a dry period in August and in September, the first ftoods of the post-fire year were observed on 1 and 3 October 1990. In both cases, rainfall quickly produced the peak response of the basin, which became zero a few minutes later (see Fig. 8).

Although we do not have the flow records from 5 to 25 October, the field observations and the comparisons with other ftow recording stations allow us 


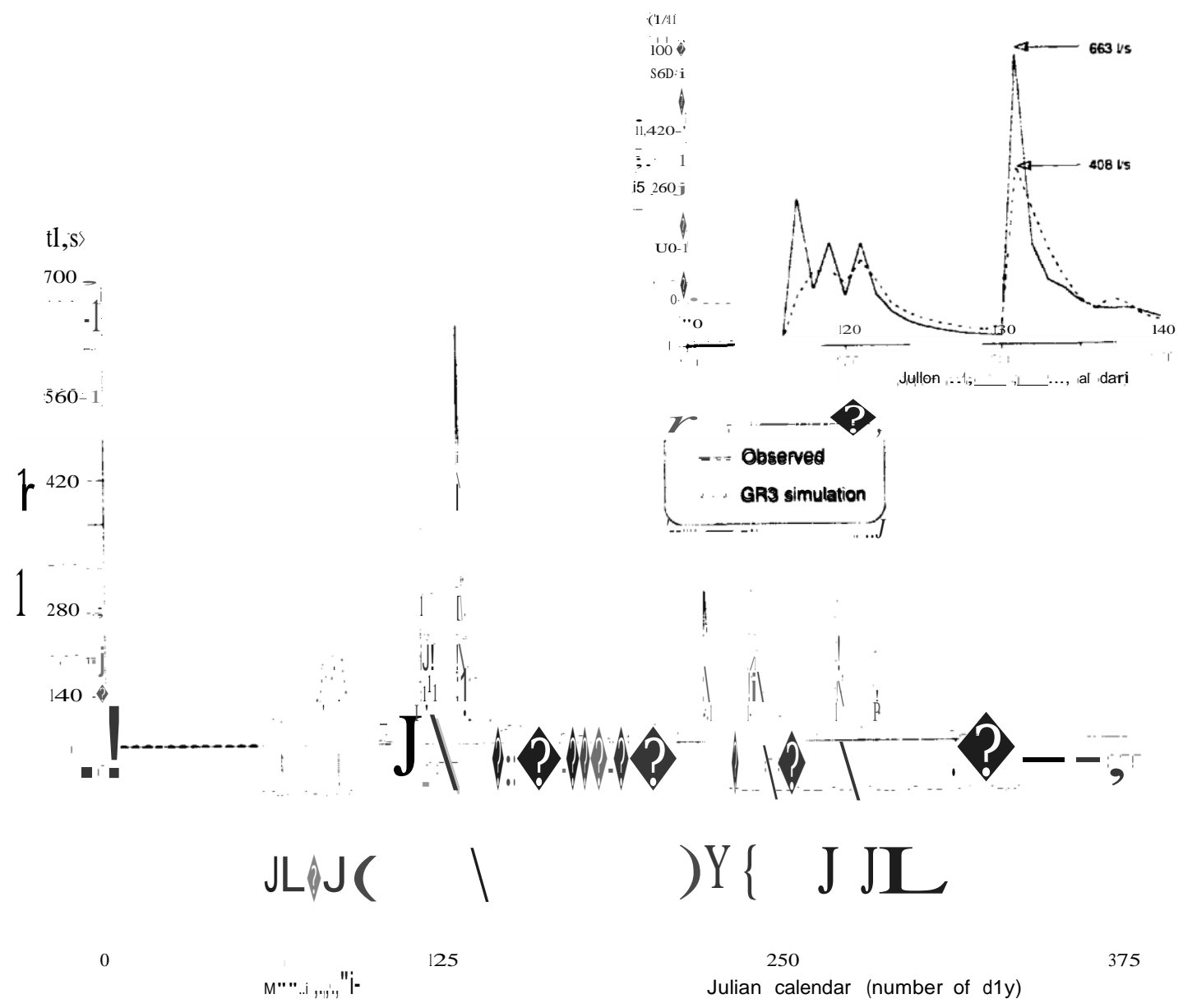

Fig. 7. Comparison bctwecn the daily runotT obscrved and simulāted by $\bar{G} \bar{R} 3$ in $1 \overline{9} \overline{9} \overline{0}$. A zoom of the two most important peaks is shown to allow better assessment of the differencé.

to locate the start of the permanent flow on 12 October. For this period the basin had some flood responses that have been lost.

From the start of the permanent flow, each rainfall gave rise to a flood event. Table 8 shows the four post-fire flood events with peaks exceeding 1 $\mathrm{m}^{\prime} \mathrm{s}^{-1} \mathrm{~km}$ ? (three of them exceeding $4 \mathrm{~m} \mathrm{~s}^{\prime \prime} \mathrm{km}-$ ?? $)$. It is worth noting that the 10 year return period flow (estimated before the fire by a Jenkinson or threeparameter Güm bel law as $6 \mathrm{~m}^{3} \mathrm{~s}^{-1}$ ) wàs exceeded three times dưring the postfire year. The most surprising is that they are not associated with excep-tional rainfall events. Compare the values shown in Täble $\overline{8}^{-}$with the I year return period of accumulated rainfall $25 \mathrm{~mm}$ in $1 \mathrm{~h}, 80 \mathrm{~mm}$ in $12 \mathrm{~h}$. (These Iyear return periods were obtained by a partial-duration frequency analysis taking into account the maximum accumulated $I h$ and -12 h rainfalls of each independent rainfall event exceeding the threshold of $13 \mathrm{~mm} \mathrm{~h}=i$ in the case of the I $\mathrm{h}$ rainfall, and $35 \mathrm{~mm} \mathrm{~h}_{-}$, in the case of the $12 \mathrm{~h}$ rainfall; Lavabre- et al., 1990.)

We can see the importance of this change in the flood regime by bearing in mind the fact that only four events exceeded $4 \mathrm{~m}^{3} \mathrm{~s}^{\prime 1} \mathrm{~km}^{-2}$ during the 23 year reference period (see Table 9). 
The post-fire events are comparable in peak flow size, but the $1 \mathrm{~h}$, and 


\section{ELOOD_ON_OCTO9ER_THE_1st_1990}

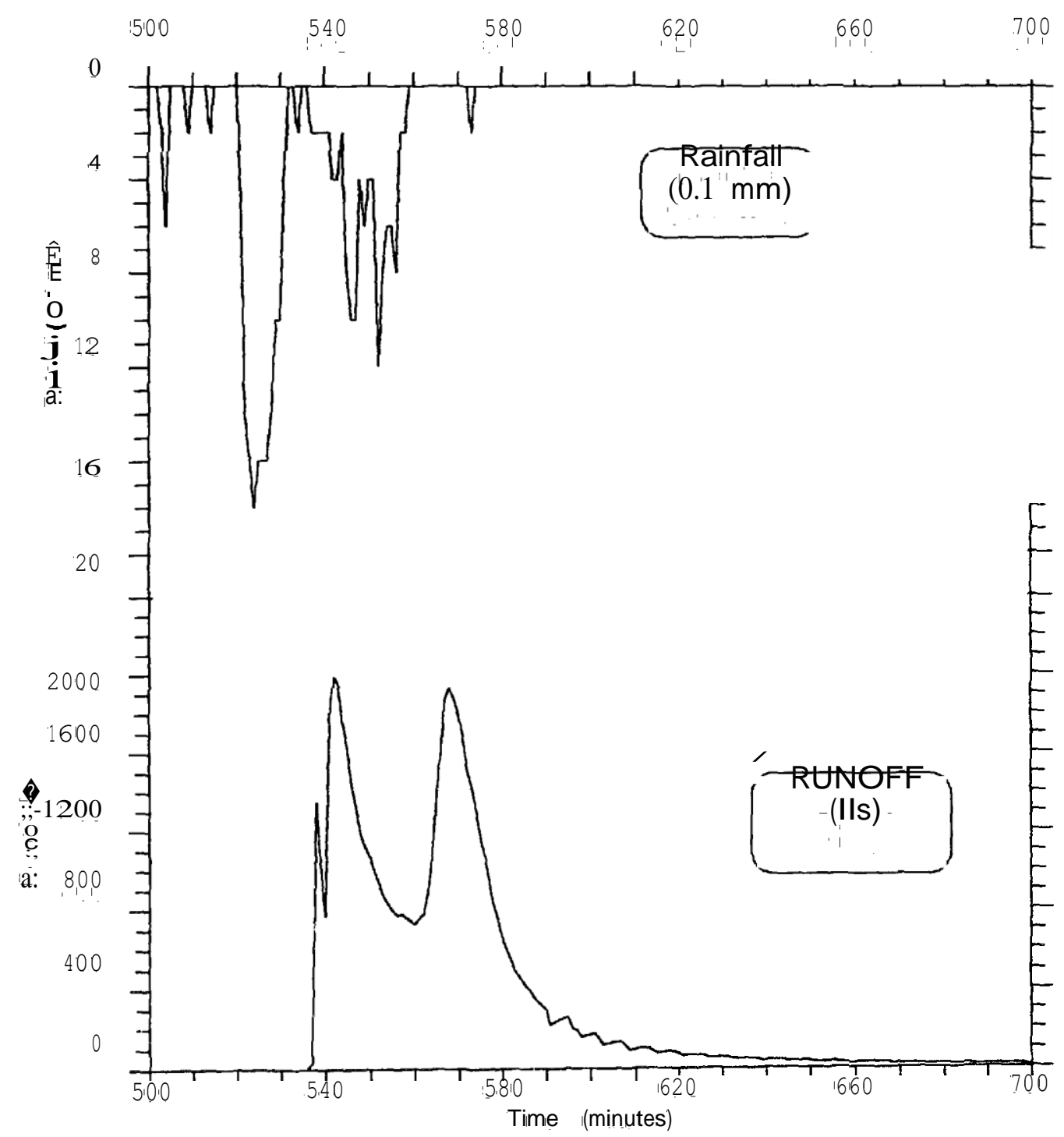

Fig. 8. Rimbaud flood event on I October 1990 at_a I min time step.

especially the $12 \mathrm{~h}$ accumulated rainfalls are much lower. To summarise we can conclude that after the fire the 1 year return period rainfall is able to produce a 10 year period peak flow, and it was recorded three times in this year.

Figures 8 and 9 show two of the post-fire flood events at a 1 min time step. The runoff response of the basin is now produced immediately after the rainfall (ony a few minutes later) giving rise to important peaks, which also fall very quickly, but with low water yield. 
TABLE 8

Flood events in 1990

\begin{tabular}{|c|c|c|c|c|c|}
\hline \multirow[t]{2}{*}{ Date } & \multirow[t]{2}{*}{$\begin{array}{l}\text { Peak flow } \\
\text { (rrr's -1) }\end{array}$} & \multicolumn{2}{|c|}{$\begin{array}{l}\text { Total water yield } \\
(\mathrm{mm})\end{array}$} & \multicolumn{2}{|c|}{$\begin{array}{l}\text { Total rainfall } \\
(\mathrm{mm})\end{array}$} \\
\hline & & $1 \mathrm{~h}$ & $12 \mathrm{~h}$ & lh & $12 \mathrm{~h}$ \\
\hline 1 October 1990 & 2.0 & 2.3 & 2.6 & 26 & 26 \\
\hline 3 October 1990 & 6.2 & 1.9 & 2.2 & 15 & 23 \\
\hline 25 November 1990 & 6.0 & 3.4 & 15.7 & 17 & 65 \\
\hline 9 Dccember 1990 & 8.0 & 11.8 & 32.0 & 28 & 78 \\
\hline
\end{tabular}

\section{CONCLUSIONS}

We have used a 23 year period of data before the fire as a reference period providing the normal hydrological behaviour of a small Mediterranean basin $\left(1.4 \mathrm{~km}^{2}\right)$.

Sorne linear regressions and a lumped conceptual hydrological model were calibrated in this reference period. They were used to assess what the response of the basin would have been if the fire had not taken place. The comparison between these results and the data observed have served to point out the changes in hydrological behaviour of the basin due to the consequences of fire.

Two main aspects were checked: (1) the changes on the annual runoff yield and (2) the changes in the flood regime.

(1) As for the annual runoff, we used five independent methods, with different time steps, of assessing the increment produced after the fire. Table 10 shows these evaluations.

To summarise, the increment can be evaluated to be approximately between 25 and $30 \%$ of supplementary runoff (about 130mm), which cannot be explained either by hazard fluctuations or by climate fluctuations.

We suggest that this change is due to the consequences of the fire, and

\section{TABLE 9}

Flood cvents in the rcfercnce period (1967-1989)

$\begin{array}{lccc}\text { Date } & \begin{array}{l}\text { Peak flow } \\ (\mathrm{m} 3 \mathrm{~s}-1)\end{array} & \begin{array}{c}\text { rh } \\ \text { rainfall }(\mathrm{mm})\end{array} & \begin{array}{c}2 \mathrm{~h} \\ \text { rainfall }(\mathrm{mm})\end{array} \\ \text { September } 1968 & 13.7 & 89 & 158 \\ \text { October } 1973 & 9.1 & 58 & 150 \\ \text { April } 1976 & 4.8 & 18 & 120 \\ \text { October } 1987 & 4.8 & 41 & 100\end{array}$




\section{FLOOD_ON_DECEMBER_THE_9th_ 1990}

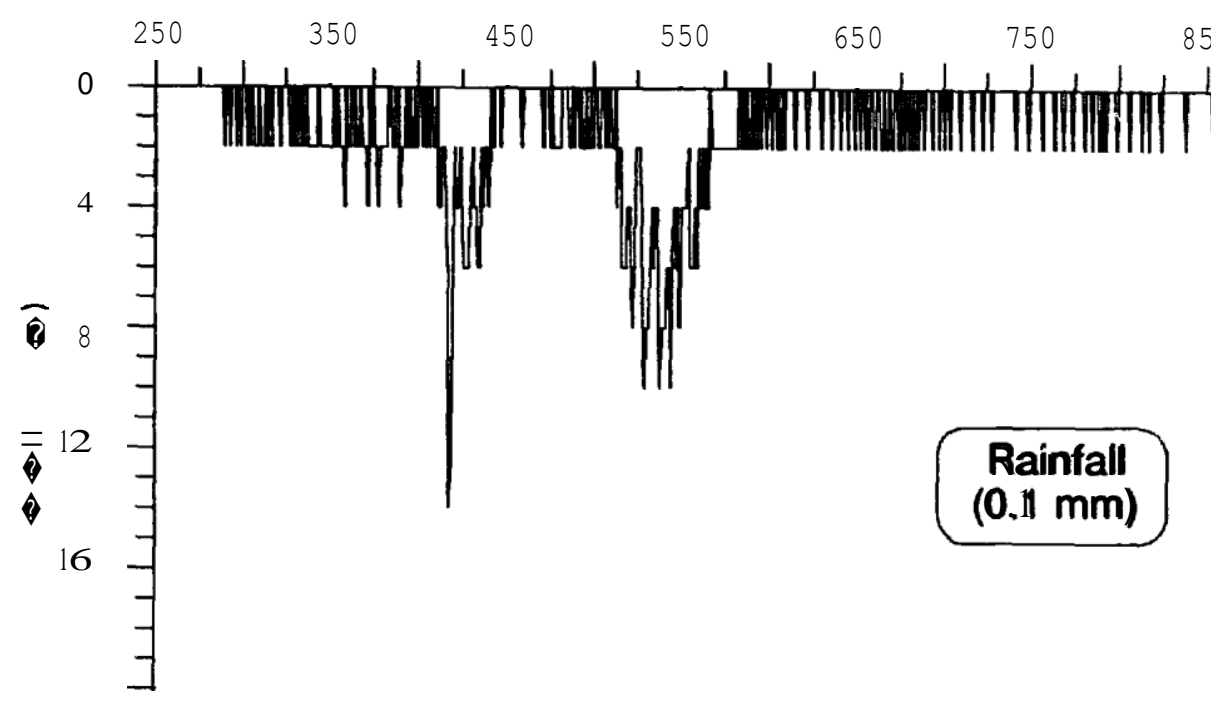

9000

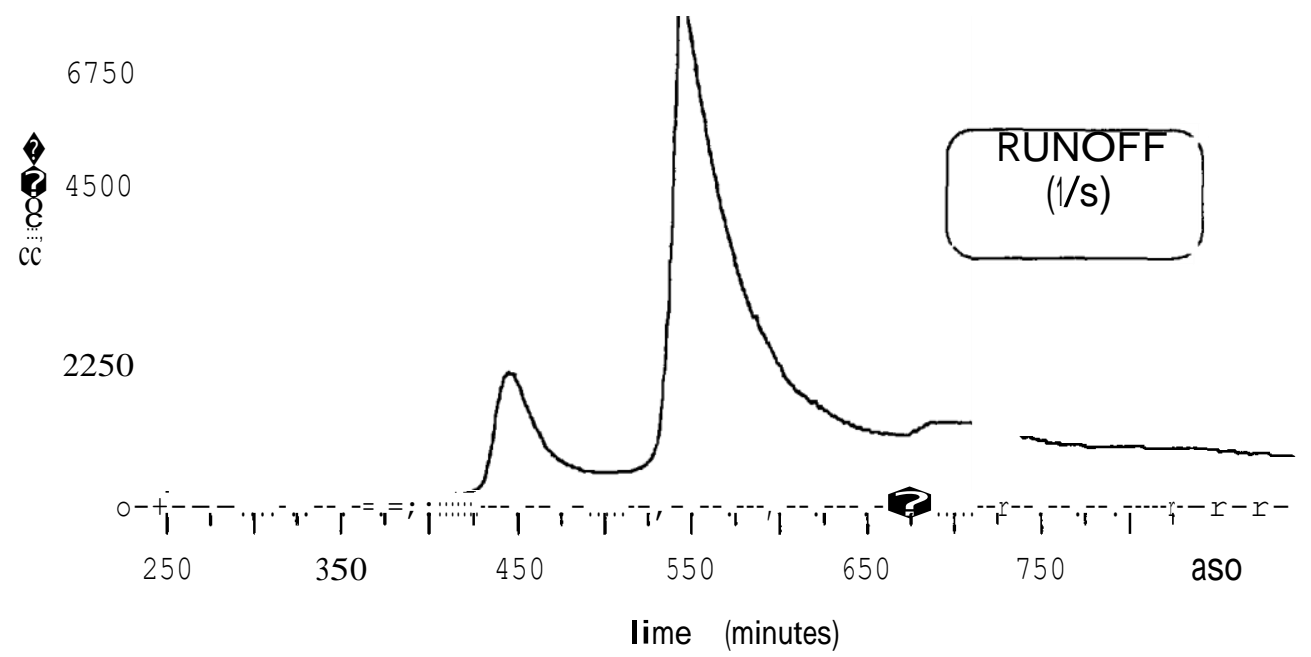

Fig. 9. Rimbaud flood event on 9 December 1990 at a I min time step.

particularly to the destruction of the vegetation cover. Using the lumped conceptual model, we tested if a simple change in the evapotranspiration amounts can lead to a better reproduction of the observed monthly runoff, The results showed that the reduction of tosses is hydrologically equivalent to applying the model in a new environment where the potential evapotranspiration is reduced by $50 \%$ (without changing either the model conceptualisation or the previously calibrated parameters).

It shows that the main hydrological change induced by the fire, at least at 


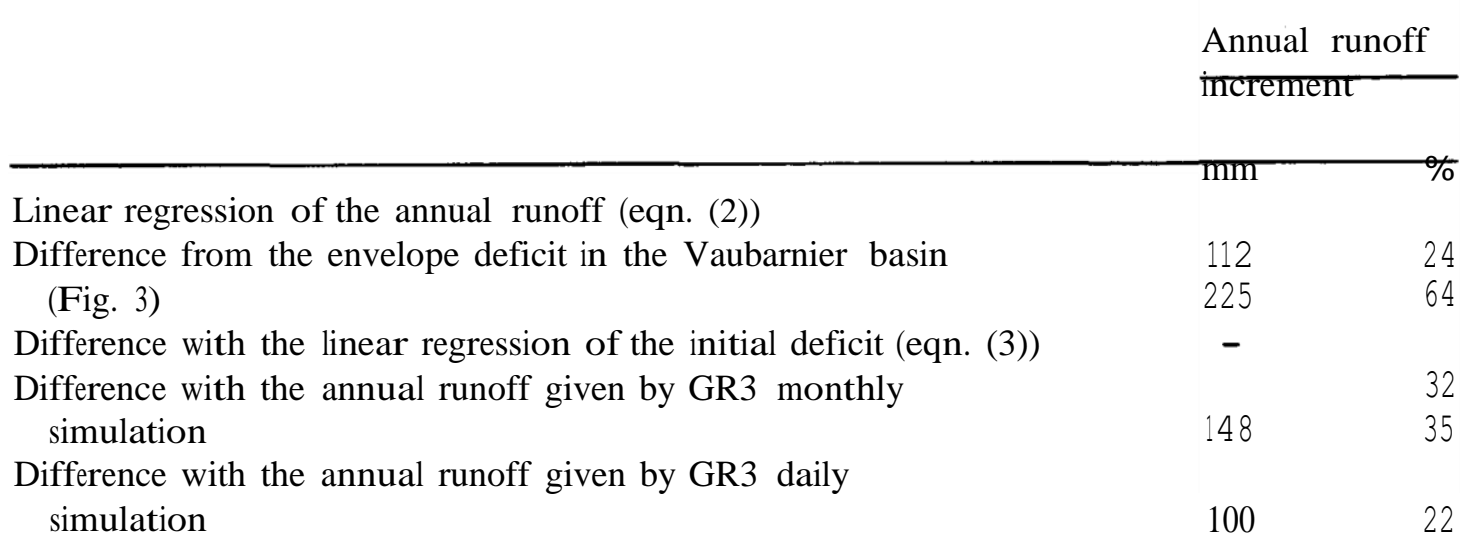

monthly and yearly time steps, is the reduction of the loss power or equivalently the increment of the annual runoff yield. At the daily step, the increase of runoff production is strictly related to the high water days and especially to the peaks of flow.

(2) As for the flood regime, the destruction of the vegetation cover and soil alteration by fire have more crucial consequences.

The retention power of soil and vegetation is lost, and the hydrological mechanisms producing runoff are significantly changed. We stated that the frequency of floods is significantly altered. The 10 year return period flow was exceeded three times in the post-fire year by rainfall events which did not exceed the yearly return period of the $12 \mathrm{~h}$ rainfall.

This evidence may lead to the suggestion that, at least, the change in flood frequency is that it converts the 10 year return period flow into a. 1 year return period', However, we should note how highly dubious these extrapolations are. Therefore we prefer to stress the extreme fragility of the usual methods of rare frequency flood evaluation, which are based on extrapolations of data of a period of a few years (note that the probability of a fire or another important change in the basin conditions will be, of course, higher).

However, an important repercussion can be stated. The results found here indicate that the hydrological consequences of fire will also affect the hydraulic works and the drainage networks (normally dimensioned to the 10 year return period flow), since the changes in the hydrological response would make the design frequency analysis obsolete. Furthermore, in areas of considerable fire risk it could be interesting to think how to take the eventuality of a fire into account in the design flood. 
On the other band, the changes in the flood regime concern the shape of the hydrographs. The post-fire responses recorded are sharper and quicker, becoming almost impulse responses. In fact, runoff does not require previous saturation of the basin, and therefore water immediately reaches the drainage network since the retention power is lost. However, more precise studies are required to assess the changes produced in mechanisms acting in the runoff generation at short time steps.

These conclusions are related to the changes in the hydrological response of the basin I year after the fire. Of course, the hydrological consequences of fire, like any others, will evolve with time controlled by vegetation growth and erosion processes. Therefore this study can be taken as if it was the first 'photograph' of the basin a year after the fire. Comparison with complementary 'photographs', taken during subsequent years, will be needed to describe the evolution of the hydrological consequences of fire with time.

Thus this work should be a starting point for in-depth studies of more accurate flood descriptions (using models of flood generation), and also for comparing basins affected to different degrees and analysing the evolution of the response during subsequent years. These studies are currently in progress.

\section{ACKNOWLEDGEMENTS}

This study has been carried out mainly through financial support from the French Ministère de la Recherche 'Scientifique and from the Conseil Régional Provence-Alpes-Côte d'Azur. The authors have also been supported by a Personal Investigador Altament Qualificat contract from the Generalitat de Catalunya, financial aid from the Spanish Plan Nacional NAT89-1072-C0601 and by a BDI grant from the C.N:R.S. Thanks are also due to C. Michel, of the CEMAGREF, for allowing us to use the GR3 model and to R. Rycroft of the Servei d'assessorament Linguiistic (Universitat de Barcelona) for the English corrections.

\section{REFERENCESa}

Anderson, H.W., 1949. Does burning increase surface runoff? J. For., 47: 54-57.

Anderson, H.W., Hoover, M.D, and Reinhart, K.G., 197.6. Forests and water ' effects of forest management on ftoods, sedimentation and water supply. USDA For.. Serv. Rep., 'Gen. Tech. Rep., PSW-18, Berkeley, CA.

\footnotetext{
"The CEMAGREF and the GIS-Réa] Collobrier reports are available on written request to Mr. Jacques Lavabre. Copies of the Institut National Polytechnique de Grenoble (INPG) Ph.D. thesis are available on written request to Atelier National de reproduction des thèses. B.P. 47X. F-38040 Grenoble, Cedex, France.
} 
Brown. J.A.H $\cdot$ 1972. Hydrologie effects of a bushfire in a catchment in south-eastern New South Wales. J. Hydrol., 15: 77-96.

Burch, G.J., Bath, R.K., Moore, J.O. and O'Loughlin, E./M., 1987. Comparative hydrological behaviour of forested and cleared catchments in southeastern Australia.. J. Hydrol., 90: 19-42.

Campbell, R.E., Baker, M.B.J., Ffolliott, P.F., Larson, L.R. and Avery, C.C., 1977. Wildfire effects on a ponderosa pine ecosystem: an Arizona case study. USDA For. Serv. Rep., Res. Pap. RM-191, Rocky Mountain For. Range Exp. Stn., Fort Collins, CO, 12 pp.

Chandler, C., Cheney, P., Thomas, P., Trabaud, L. and Williams, D., 1983. Fire effects on soil, water and air. In: Fire in Forestry, Vol. 1: Forest fire behaviour and effects. Wiley, New York, pp. 171-202.

Corrnary, Y, and Guilbot, A., 1973. Etude des relations pluie-débit sur trois basins versants représentatifs, ln: IAHS Pub. No. 108, Wallingford, pp. 265-279.

Editjano and Michel, $\mathrm{C}_{1}$, 1989, Un modèle pluie-débit journalier à trois paramètres. . La Houille Blanche, 2: 113-121.

Editjano, Michel, C. and Leviandier, T., 1991. Daily lumped rainfall-runoff model with three free parameters. CEMAGREF Rep, Antony, France, $21 \mathrm{pp}$.

Gustard, A., Roald, L.A., Delmuth, S.o Lumadjens, H.S. and Gross, R., 1989. Flow regimes from experimental and network data (FREND). Vol. 1: 'hydrological studies. 'nstitute of Hydrology (Editor), Wallingford, $344 \mathrm{pp}$.

Lavabre, J, 1989. Research drainage basin of the Réal Collobrier (Mediterranean, France). Flow modelization and regional anaiysis. ln: FRIENDS in Hydrology . Flow regimes from international experimental and network data sets). IAHS Publ. No. 187, Wallingford, pp. $423-434$.

Lavabre, J., 1990. Bassin versant représentatif et d'étude du Réal Collobrier. GIS-Réal Collobrier Rep, Aix-en-Provence, 21 pp.

Lavabrc, J., Martin, C. and Puech, C., 1991. Les feux de forêts de l'été 1990 dans le massif des Maures: cartographie à l'aide de l'imagerie satellitaire, premières consequences sur le cycle hydrologique, recherches sur les phénomènes d'érosion. Secheresse, 2: 175-181.

Lavabre, J., Martin, C. and Wolff, M - 1990. B.V.R.E. du Réal Collobrier. Cartographie de d'épisode pluvieux. du premier octobre 1990. GIS-Réal Collobrier Rep., Aix-en-Provence, $29 \mathrm{pp}$ :

Loumagne, C, Michel, C. and Normand, M., 1991. Etat hydrique du sol el prévision des dẹbits (soil-moisture conditions and discharge forecasting). J. Hydrol., 123: 1-17.

L'vovich, M.1., 1972. Hydrologie budget of continents and estimate of the balance of global fresh water resources. Sov. Hydrol., 4: 349-360.

Martin, C. and Chevalier, Y., 1991. Premières conséquences d'un incendie for forêt sur le comportement hydrochimie du bassin versant du rimbaud. Hydrol. Continent, 6(2): 145-153.

Michel, C., 1983. Que peut-on faire en hydrologie avec un modèle conceptuel à un seul paramètre. La Houille Blanche, i: 39-44.

Michel, C., 1989. Hydrologie appliquée aux bassins versants ruraux. CEMAGREF Rep., Antony (France), 510 pp.

Nash, J.E. and Sutcliffe, J.V., 1970. River ftow forecasting through conceptual models, I. A discussion of principles. J. Hydrol., 10: 282-290.

Rowe, P.B., Countryman, C.M. and Storey, H.C., 1954. Hydrologie analysis used to determine etfects of fire on peak discharge and erosion rates in southern California watershed. U.S. For. S̄erv. Rep., Unnumbered Rep., Beltsville, MD, 49 pp. 
Scott, D.F. and van Wyn, D.B., 1990. The effects ofwildfire on soil wettability and hydrological behaviour of an afforested catchment. J. Hydrol., 121: 239-256.

Sempere Torres, D., 1990. Calcul de la lame ruisselée dans la modélisation pluie-débit: limitations des approches globales et introduction simplifiée de la topographie et de la variabilité spatiale des pluies. Ph.D. Thesis, Institut National Polytechnique de Grenoble.

Sempere Torres, D., 1992a. GR3: un model conceptual simple de transformaciô pluja-cabal a escalade conca vessant. UPC-Dept. Hydraul. Eng., Rep. 32/C2-5.92, Barcelona, 8 pp.

Servat, E. and Dezeiter, A., 1991. Selection of calibration objective functions in the context of rainfall-runoff modelling in a Sudanese savannah area. Hydrol. Sei. J., 36: 307-330.

Tiedemann, A.R., Conrad, C.E., Dieterich, J.H., Hombeek, J.W., Megahan, W.F., Viereck, LA. and Wade, D.D., 1979. Effects of fire on water: astate of knowledge review. USDA For. Serv. Rep., Gen. Tech. Rep. WP-10, Washington, D.C.

APPENDIX: A BRIEF DESCRIPTION OF THE GR3 MODEL

(From Sempere Torres, 1992a)

Although it is not our aim to describe fully the GR3 model (see for instance Michel, 1983; Michel, 1989; Editjano and Michel, 1989; Servat and Dezeiter, 1991; Loumagne et al., 1991), we thought it would be interesting to review its main points briefly.

GR3 is a lumped conceptual model proposed by Michel (1983) based on the work of Cormary and Guilbot (1973). It is a two-reservoir model that needs to calibrate only two or three parameters depending on the time step that is used. It is the reference rainfall-runoff model used in the CEMAGREF studies. In our work we used it with a monthly and a daily time step. Essentially the model is the same, but the daily version introduces some small modifications to fit daily hyetographs better.

First we will summarize the general description and afterwards we will describe the modifications used in the daily time step version.

GR3 is made up of two reservoirs (see Fig. A1): the soil moisture reservoir and the routing reservoir. The storage of the soil moisture reservoir, $S$, controis the evapotranspiration losses and therefore the portion of water that will constitute the runoff. lts maximal storage, $A$, is the first parameter of the model. The routing reservoir controls the outflow, $Q$, which is a monotonie fonction of its storage $R$. 1 ts maximal storage, $B$, is the second parameter of the model.

As inputs, GR3 needs precipitation, $P$, and potential evapotranspiration, $E$, during the time step considered (we used interannual means of the evapotranspiration measured at the next meteorological station in our case study). Depending on whether the difference $P^{\prime}=P-E$ is less or greater than zero, there will be two cases:

(1) If $P^{\prime}<0$, there will be a loss due to evapotranspiration. In this case the 

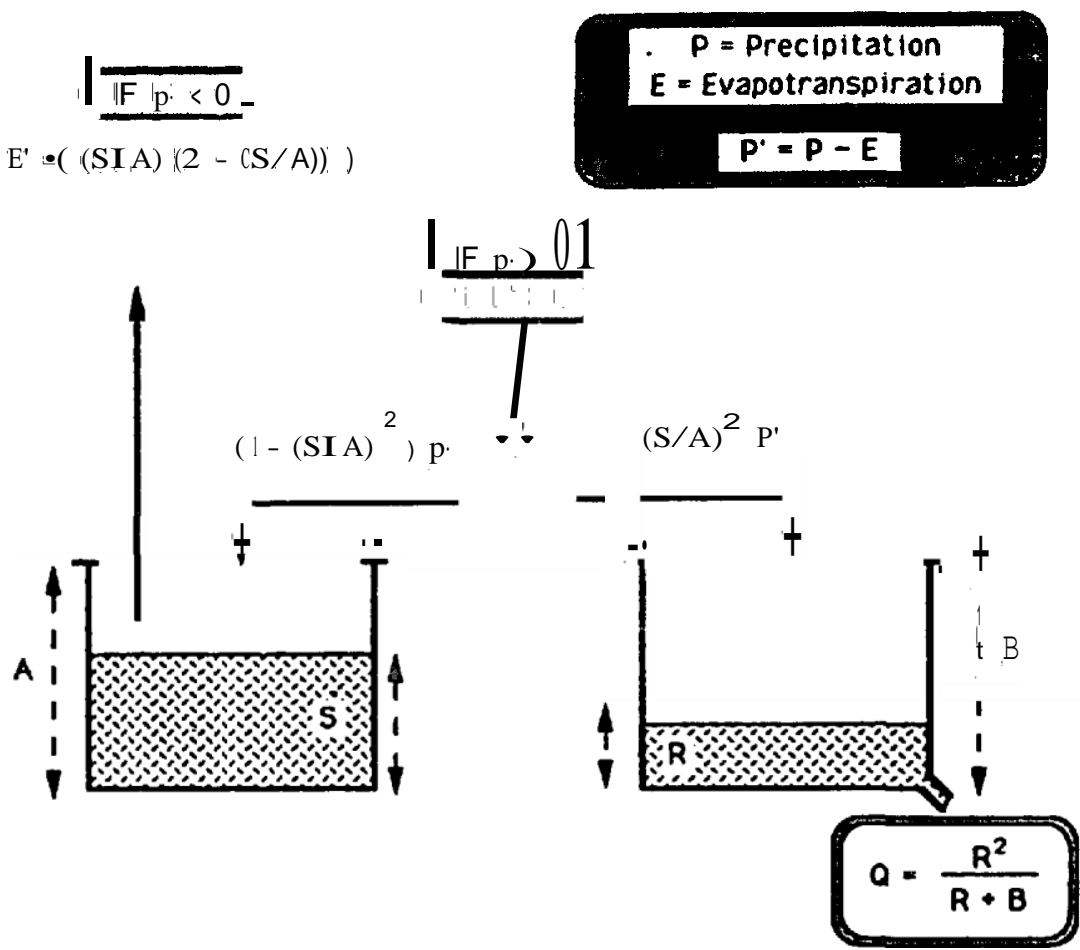

Fig. A 1. Diagram of the GR3 rainfall-runoff mode!.

soil moisture reservoir is emptying as (Editjano and Michel, 1989)

$$
\mathrm{d} S=-\left[\frac{S}{A}\left(2-\frac{S}{A}\right)\right] \mathrm{d} E^{\prime}
$$

where $E^{\prime}$ is $E-P$. Therefore, there is no water available to produce runoff and the outflow is reduced to the routing reservoir emptying;

(2) if $P^{\prime}>0$, there are no evapotranspiration losses from the soil moisture reservoir, and the water uvailable $P^{\prime}$ will be divided into two terms: $\mid[1-$ - $(S)$ Af] $P^{\prime}$ will be retained by the soil moisture reservoir increasing its storage level, $S$, and the complementary portion, $(\mathrm{S} / \mathrm{A})^{2} P^{\prime}$ will refill the routing reservoir.

As for the routing reservoir, we will consider that this emptying in absence of refill is a quadratic relation of the storage level $R$ (Editjano and Michel, 1989)

$$
d t=-k R 2
$$

So the outflow during a time step is given by

$$
Q=\frac{\mathrm{R} 2}{\mathbb{m}+\mathbb{m}}
$$


where $B \boldsymbol{i}$ s the maximal storage.

This scheme, repeated each time step, is used with the monthly version. However, to fit better the hydrographs observed at daily time step it is necessary to add both a third module and a third parameter.

At daily and lower time steps it is necessary to introduce a time delay to the peak since rainfall does not usually have an immediate response. To incorporate this time delay, a delay function, rather similar to the isochrone notion, is added to the model. It bas an imposed parabolic structure, and the only parameter to supply is the total time delay, $\mathrm{C}$, since its integral must be unity to preserve the volume conservation (see Editjano and Michel, 1989). The parameters $A$ and $B$ (plus $C$ in the case of the daily simulation) are optimised using a gradient method by minimisation of the sum of the squared residuals between observed and simulated runoff.

Finally some recent improvements have been incorporated in the daily version (Editjano et al., 1991). As for the routing reservoir emptying, a general power fonction instead of the previous quadratic fonction is used. The new power used was five instead of two, allowing the recession curve to fit better than previously. Additionally, after the separation of the term that will produce runoff, only $90 \%$ of it $\left(0.9(\mathrm{~S} / \mathrm{A})^{2} \mathrm{P}^{\prime}\right)$ is now delayed and routed, and the other $10 \%$ is directly used to give rise to the outflow. Thus Qat each time step will be the addition of two terms: the $10 \%$ of the available water at this step, $\left(0.1(\mathrm{~S} / \mathrm{A})^{2} \mathrm{P}^{\prime}\right)$, and the outflow produced by the routing reservoir which is in fact the result of the previous rainfall. Editjano et al. (1991) found that this modification allows the model to fit quick runoff responses better. 